\title{
PEMBERDAYAAN SEKOLAH DALAM PENGELOLAAN SAMPAH SEBAGAI BAHAN PEMBELAJARAN PENDIDIKAN LINGKUNGAN HIDUP (PLH)
}

\author{
Windarto $^{1}$, Martini $^{2}$ \\ ${ }^{1}$ Teknologi Informasi, Universitas Budi Luhur, Jakarta, Indonesia \\ ${ }^{2}$ Akuntansi, Universitas Budi Luhur, Jakarta, Indonesia \\ windarto@budiluhur.ac.id, martini@budiluhur.ac.id
}

\begin{abstract}
Abstrak
Indonesia memiliki predikat sebagai penyumbang sampah nomer 2 di dunia. Sekolah sebagai tempat berkumpulnya banyak orang dapat menjadi penghasil sampah terbesar selain pasar, rumah tangga, industri dan perkantoran. Sampah yang dihasilkan sekolah kebanyakan adalah jenis sampah kering dan hanya sedikit sampah basah. Sampah kering yang dihasilkan kebanyakan berupa kertas, plastik dan sedikit logam. Sedangkan sampah basah berasal dari guguran daun pohon, sisa makanan dan daun pisang pembungkus makanan. Sekolah dapat dipakai sebagai media pembelajaran bagi siswa-siswinya. Salah satu parameter sekolah yang baik adalah berwawasan lingkungan. Dengan sistem pemilahan ini diharapkan anak didik dapat belajar betapa sampah yang semula kotor dan menjijikkan ternyata memiliki nilai jual. Mata pelajaran ekonomi dapat dipelajari dari seonggok sampah di sekolah. Anak didik akan menyadari bahwa peluang kerja ada di sekitarnya, bukan hanya dicari tapi dapat juga diciptakan. Dalam perancangan pengelolaan sampah di sekolah, para siswa perlu dilibatkan secara aktif. Kegiatan pameran dan kompetisi berkala dapat dilakukan untuk meningkatkan kepedulian terhadap pengelolaan sampah. Menulis di blog atau majalah dinding merupakan latihan yang bagus untuk menumbuhkan jiwa-jiwa mengelola sampah. Sehingga muncul kesadaran baru bahwa, "Sampah bukan masalah, tetapi peluang".
\end{abstract}

Kata Kunci: Recycle, Reuse, Sampah, Produk Kreatif.

\section{PENDAHULUAN}

Permasalahan lingkungan telah menjadi isu global (mendunia), setelah hampir semua elemen masyarakat menyadari akan bahaya yang ditimbulkan dari kerusakan lingkungan. Salah satu penyebab kerusakan lingkungan adalah pencemaran lingkungan yang disebabkan oleh menumpuknya limbah yang dihasilkan oleh manusia. Limbah adalah segala sesuatu yang sudah tidak terpakai lagi sebagai barang produksi maupun konsumsi, yang jika langsung dibuang ke lingkungan tanpa pengolahan terlebih dahulu dapat menjadi beban bagi lingkungan.

Bermacam limbah yang dihasilkan oleh aktivitas manusia setiap harinya, ada yang berujud padat, cair maupun gas. Limbah yang berujud padat biasa disebut dengan sampah. Beragam aktivitas manusia dapat menimbulkan sampah, baik aktivitas industri, pertanian, rumah sakit, maupun aktivitas domestik (rumah tangga). Berbagai macam limbah atau sampah tersebut jika hanya langsung dibuang ke lingkungan maka akan menyebabkan pencemaran lingkungan dan kerusakan lingkungan, yang pada

$$
\text { Ekonomi, Sosial dan Budaya }
$$

1210 
akhirnya akan merugikan manusia sendiri. (Wicaksana, dkk 2018).

Pemerintah saat ini tengah fokus mengatasi pengelolaan sampah plastik. Bahkan Menteri Kelautan dan Perikanan Susi Pudjiastuti pernah menyebut Indonesia sebagai negara penyumbang sampah plastik terbesar ke-2 di dunia. Asosiasi Industri Plastik Indonesia (INAPLAS) memaparkan, total konsumsi plastik di Indonesia adalah 5,76 juta ton per tahun dengan rata-rata konsumsi per kapita sebesar 19,8 kg padahal konsumsi plastik di Indonesia, terbilang masih rendah dibandingkan dengan negara-negara maju. Kenapa kita hanya 20 kilogram (konsumsi plastik per kapita per tahun) disebut nomor 2 sebagai penyumbang sampah plastik? Bagaimana mungkin konsumsi rendah kita jadi pengotor. Jadi (penyebabnya) waste management (pengelolaan), di luar negeri jauh lebih maju dibandingkan kita. (kumparan.com)

Penanganan sampah plastik secara nasional dapat diatasi dengan baik, jika program waste management atau pengelolaan sampah plastik dapat diterapkan secara masif. Ketua Umum Asosiasi Daur Ulang Plastik Indonesia (Adupi) Christine Halim mengatakan, kebijakan pelarangan plastik perlu ditinjau ulang karena aturan tersebut bukan satusatunya penyelesaian masalah plastik. Kebijakan pelarangan tidak dipertimbangkan dampak holistik dengan kajian keilmuan yang telah dipublikasikan. (kompas.com)

Menurutnya, pengelolaan sampah plastik merupakan langkah yang tepat karena plastik adalah objek diam yang tidak punya kaki untuk berpindah tempat atau berniat mencemari lingkungan. Diperlukan program edukasi dan budaya di masyarakat untuk pengumpulan, pemilahan dan pembuangan sampah plastik pada tempatnya. Secara terisah, Ketua Ikatan Pemulung Indonesia (IPI) Pris Polly Lengkong mengatakan, ada 3,7 juta orang di 25 provinsi bergantung pada sampah plastik dan sampah daur ulang lain dalam mencari nafkah. Pengurangan atau pelarangan plastik sudah pasti akan mengurangi pendapatan pemulung. IPI mengharapkan adanya sirkulasi ekonomi daur ulang ditingkatkan, khususnya pada kantong plastik kresek agar ada peningkatan pendapatan pemulung. (kumparan.com).
Sampah yang dihasilkan sekolah kebanyakan adalah jenis sampah kering dan hanya sedikit sampah basah. Sampah kering yang dihasilkan kebanyakan berupa kertas, plastik dan sedikit logam. Sedangkan sampah basah berasal dari guguran daun pohon, sisa makanan dan daun pisang pembungkus makanan. Jenis sampah yang juga lumayan banyak di sekolah adalah plastik. Sampah ini sebagian besar terdiri dari bungkus plastik dan botol minuman mineral. Untuk jenis terakhir inilah yang sekarang banyak dicari orang. Botol minuman bekas yang berbahan plastik PET bisa didaur ulang menjadi biji plastik. Demikian juga halnya dengan kaleng minuman bekas yang berbahan logam. Sampah jenis ini juga sebaiknya dipilah, dikumpulkan untuk kemudian dijual. Anak-anak juga dapat berkreasi merangkainya menjadi barang kerajinan atau hiasan dinding.

Dengan sistem pemilahan ini diharapkan anak didik dapat belajar betapa sampah yang semula kotor dan menjijikkan ternyata memiliki nilai jual. Mata pelajaran ekonomi dapat dipelajari dari seonggok sampah di sekolah. Anak didik akan menyadari bahwa peluang kerja ada di sekitarnya, bukan hanya dicari tapi dapat juga diciptakan.

Dalam perancangan pengelolaan sampah di sekolah, para siswa perlu dilibatkan secara aktif. Hal ini dapat dilakukan dengan pembentukan regu-regu yang bertugas secara terjadwal. Kegiatan pameran dan kompetisi berkala dapat dilakukan untuk meningkatkan kepedulian terhadap pengelolaan sampah. Menulis di blog atau majalah dinding merupakan latihan yang bagus untuk menumbuhkan jiwa-jiwa mengelola sampah. Sehingga muncul kesadaran baru bahwa, "Sampah bukan masalah, tetapi peluang".

Sekolah menduduki posisi strategis dalam menumbuhkan wawasan lingkungan hidup dan membina kesadaran generasi muda agar berprilaku arif terhadap lingkungan. Budaya hemat sumberdaya alam dan ramah lingkungan tidak dapat tumbuh dengan sendirinya tanpa upaya pembiasaan sejak dari masa anak-anak. Pengelolaan sekolah yang didesain sebagai laboratorium alam akan menjadi wahana pembelajaran yang efektif terhadap pembentukan budaya tersebut.

Ekonomi, Sosial dan Budaya 1211 


\begin{abstract}
Dengan menjadikan peduli lingkungan sebagai paradigma, etika dan perilaku kehidupan bagi warga sekolah, maka segala aktivitas akan selalu memperhatikan kesehatan individu dan lingkungan sekitarnya. Dengan demikian terciptalah lingkungan bersih, indah, nyaman dan menyehatkan yang pada gilirannya dapat menuju kualitas lingkungan hidup yang layak bagi kehidupan manusia dan makhluk hidup lain dan ini dapat merangsang warga sekolah dan tamu betah di sekolah serta memberikan keteladanan kepada masyarakat tentang kepedulian dan tanggung jawab dalam menciptakan lingkungan asri dan menyehatkan.
\end{abstract}

Lewat kegiatan-kegiatan ini semua warga sekolah (terutama para siswa) akan memperoleh pendidikan lingkungan hidup dalam bentuk wawasan/pengetahuan dan keterampilan untuk mengaplikasikannya serta pembiasaan perilaku/pembentukan budaya. Mereka tidak hanya sekedar tahu tetapi mampu menerapkannya dalam kehidupan sehari-hari. Kegiatan utama diarahkan pada terwujudnya sekolah sebagai sumber belajar pendidikan lingkungan hidup.

Dalam hal ini kami akan melakukan pengabdian kepada masyarakat dengan memilih topic mengenai pengelolaan dan pemberdayaan sampah. Keberhasilan upaya ini sangat ditentukan oleh keinginan dan tekad yang kuat dari semua warga sekolah untuk menjaga kelestarian lingkungan hidup. Kita berharap semua sekolah dapat memperlihatkan kondisi bangunan dan lingkungan yang aman, sejuk, rindang, indah, nyaman, menyehatkan dan tidak mengganggu lingkungan sekitarnya serta perilaku warganya yang peduli lingkungan. Dengan terwujudnya siswa yang peduli lingkungan semoga terjadi akumulasi dampak dansinergis di kalangan generasi yang akan datang untuk menjaga lingkungan.

SMA An-Nurmaniyah (SMA YAPERA) Merupakan Lembaga Pendidikan Yang Telah Lama Berdiri Di Tengah-Tengah Masyarakat. Sejak 1998, SMA An-Nurmaniyah (SMA YAPERA) Selalu Berkomitmen Penuh Dalam Upaya Mencerdaskan Anak Bangsa Melalui Program Pendidikan Yang
Berkualitas, Mandiri, dan Islami dengan Fasilitas yang Lengkap.

Siswa diperkenankan memilih kelas seni dan keterampilan sesuai minat dan bakat yang dimiliki. Melalui kelas ini, siswa akan dilatih dan dibantu menemukan potensi di luar bidang akademik. Salah satu bidang kelas seni yang ada di SMA YAPERA ini adalah kelas crafting. Di kelas crafting, kreatifitas merupakan unsur yang paling penting. Di kelas ini semua anak bebas berkreasi, mengungkapkan pendapat melalui sebuah karya, dan mendapat bimbingan, apresiasi dan dorongan yang positif sehingga anak lebih berani dan percaya diri dalam mengekspresikan diri.

Media yang digunakan sangat beragam, mulai dari kertas, alumunium foil, manik-manik, kapas, benang, kain, dan lain-lain. Hasil karya yang dihasilkan sangat beragam dan sangat berguna untuk menggali ide dan mengembangkan kreatifitas anakanak. Namun selama ini bahan yang mereka gunakan adalah bahan baru dan harus membeli. Untuk itu perlu diajarkan kepada para siswa bahwa berkreasi tidak harus menggunakan bahan/komponen baru, melainkan kita juga bisa memanfaatkan bahan-bahan yang sudah tidak lagi terpakai atau bahkan bahannya diperoleh dari sampah yang tadinya hanya dilihat sebelah mata untuk dimanfaatkan sebaik-baiknya sehingga menjadi produk yang bisa dilirik oleh banyak mata. Tidak hanya itu, pemanfaatan limbah/sampah yang tak terpakai ini diharapkan dapat menjadi barang yang memiliki nilai ekonomi yang pada akhirnya dapat menjadi peluang usaha.

Oleh karena itu sekolah berharap ada kerja sama lanjutan dengan perguruan tinggi (Universitas Budi Luhur) dalam hal transfer pengetahuan dan teknologi dalam rangka mengatasi persoalan limbah plastik. Plastik adalah material yang sering kita jumpai dalam kehidupan sehari-hari. Kemajuan teknologi dan industri membuat aktivitas produksi plastik terus meningkat. Pengelolaan sampah di Indonesia masih belum menjadi prioritas utama. Rata-rata akses terhadap pengelolan sampah di Indonesia kurang dari 60\%. Hal ini menunjukkan bahwa ada kemungkinan sampah akan terbuang ke lingkungan. Saat ini, industri industri minuman di Indonesia merupakan salah satu sektor yang

$$
\text { Ekonomi, Sosial dan Budaya }
$$


pertumbuhannya paling pesat. Pada kuartal I-2019, pertumbuhan industri pengolahan minuman mencapai $24,2 \%$ secara tahunan. Banyak dari hasil akhir produk minuman menggunakan plastik sekali pakai sebagai packaging. Minuman-minuman tersebut dapat dengan mudah ditemui di berbagai gerai ritel, baik modern maupun tradisional. Pertumbuhan industri minuman yang sangat pesat tentu saja akan menghasilkan pertumbuhan jumlah sampah plastik yang semakin banyak. Terlebih saat ini kapasitas pengolahan limbah plastik masih terbilang minim.

Dari data ini bisa dilihat bahwa, apabila limbah sampah ini tidak dapat dikurangi maka akan berdampak negatif bagi lingkungan dan juga alam. Dari prinsip 3R, metode yang dinilai cukup efektif dalam mengurangi dampak limbah plastik adalah metode reuse (pemanfaatan kembali) dan recycle (daur ulang). Pemanfaatan kembali, yakni berkreasi dan berinovasi menjadikan sampah plastik menjadi barang yang berguna seperti handicraft yang layak jual. Sedangkan daur ulang adalah proses menjadikan sampah platik dipersiapkan menjadi bahan baku untuk diolah lagi menjadi produk baru skala industri.

\section{METODE}

\section{Tahapan Kegiatan Pengabdian Kepada Masyarakat.}

Tahapan yang akan dilakukan untuk kegiatan pengabdian kepada masyarakat SMA An Nurmaniyah Ciledug Tangerang adalah sebagai berikut:

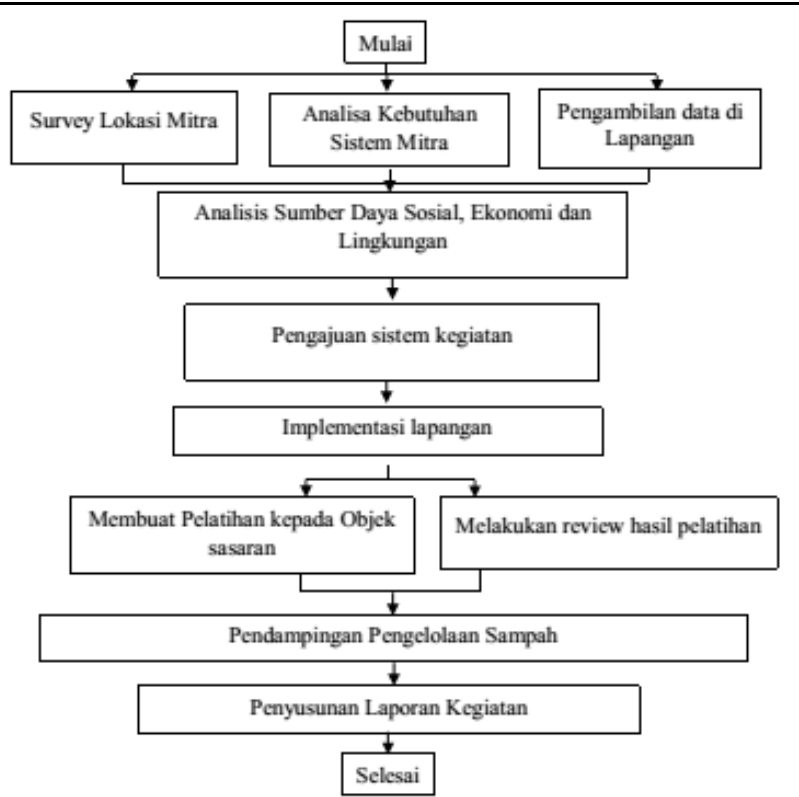

\section{Gambar 1: Tahapan Kegiatan Pengabdian Kepada Masyarakat yang di usulkan}

\section{Metode Pendekatan}

Luaran yang akan diberikan pada mitra dan khalayak sasaran adalah pengelolaan sampah nonorganik menjadi produk kreatif hasil daur ulang yang bernilai ekonomi bagi masyarakat. Hal tersebut dapat dicapai dengan membuat klinik daur ulang sampah di SMA An Nurmaniyah Ciledug Tangerang.

Pendekatan yang akan dilakukan adalah dengan memberikan pelatihan kepada warga masyarakat terutama para siswa di Klinik Daur Ulang tersebut. Adapun metode yang dipakai adalah menggunakan Metode Training of Trainner (TOT), yaitu metode ceramah kemudian langsung mempraktikkan. Pelatihan tersebut diantaranya adalah sebagai berikut:

a. Edukasi sampah Happa / Daun 

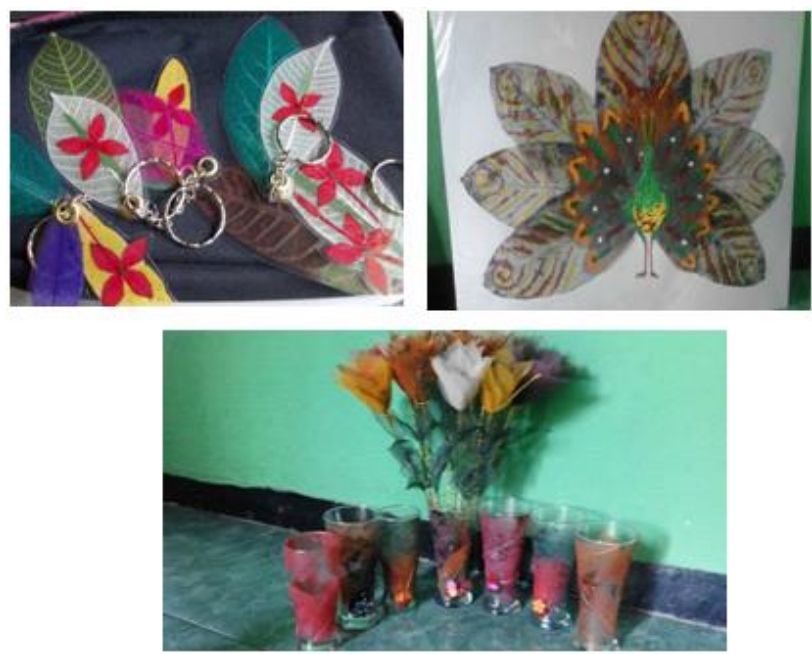

Gambar 2. Produk Kerajinan Dari Klaras

b. Edukasi sampah plastik rumah tangga.

Memberikan pelatihan mengolah sampah non organik menjadi barang yang dapat dimanfaatkan kembali. Hasil daur ulang sampah non organik tersebut dapat dimanfaatkan oleh masyarakat itu sendiri ataupun dapat dijual kepada masyarakat luar.
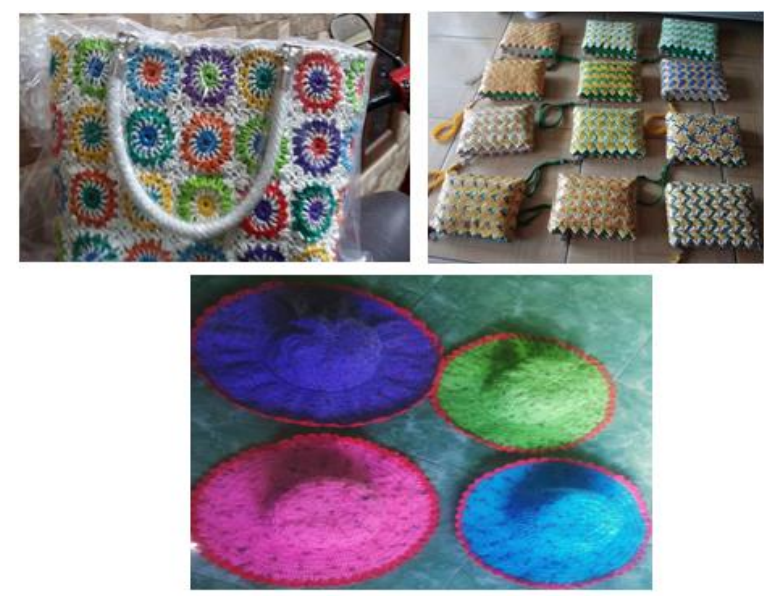

\section{Gambar. 3 Produk Daur Ulang Sampah Non Organik}

\section{Tahapan dan Pelaksanaan Program}

Tahap - tahap yang dilakukan untuk merealisasikan Pemberdayaan Sekolah Sebagai
Sumber Belajar Pendidikan Lingkungan Hidup (PLH) Melalui Pengelolaan Sampah Dalam Upaya Pencapaian Sustainable Development Goals (SDGs) Tujuan Ke-12 (Responsible Consumption and Production) ini dari tahap awal hingga tahap akhir ini antara lain:

a. Pada tahap awal perijinan pelaksanaan kegiatan.

1) Mengumpulkan informasi tentang permasalahan yang dihadapi mitra.

2) Meminta perijinan kepada Kepala Sekolah SMK An Nurmaniyah untuk melaksanakan kegiatan.

b. Pada tahap pelaksanaan kegiatan.

1) Menyediakan konsumsi saat diadakannya pelatihan tentang lingkungan hidup yang sehat, pelatihan untuk belajar mendaur ulang sampah, serta pelatihan untuk berbisnis dari hasil daur ulang sampah.

2) Menyediakan contoh produk hasil daur ulang sampah.

3) Menyediakan peralatan kerja untuk membuat produk daur ulang dari sampah non organik.

c. Pada tahap akhir melakukan pelaporan hasil pelaksanaan kegiatan.

\section{HASIL DAN PEMBAHASAN}

Kegiatan Pemberdayaan Sekolah Sebagai Sumber Belajar Pendidikan Lingkungan Hidup (PLH) Melalui Pengelolaan Sampah Dalam Upaya Pencapaian Sustainable Development Goals (SDGs) Tujuan Ke-12 (Responsible Consumption And Production ini telah dilaksanakan pada tanggal 31 Oktober 2019 pukul 08.00 WIB - selesai di SMA An Nurmaniyah Ciledug Tangerang.

Peserta yang terlibat dalam kegiatan ini terdiri dari 18 orang peserta didik, 1 orang pembina serta 2 orang pendamping dari SMA An Nurmaniyah Ciledug Tangerang. 


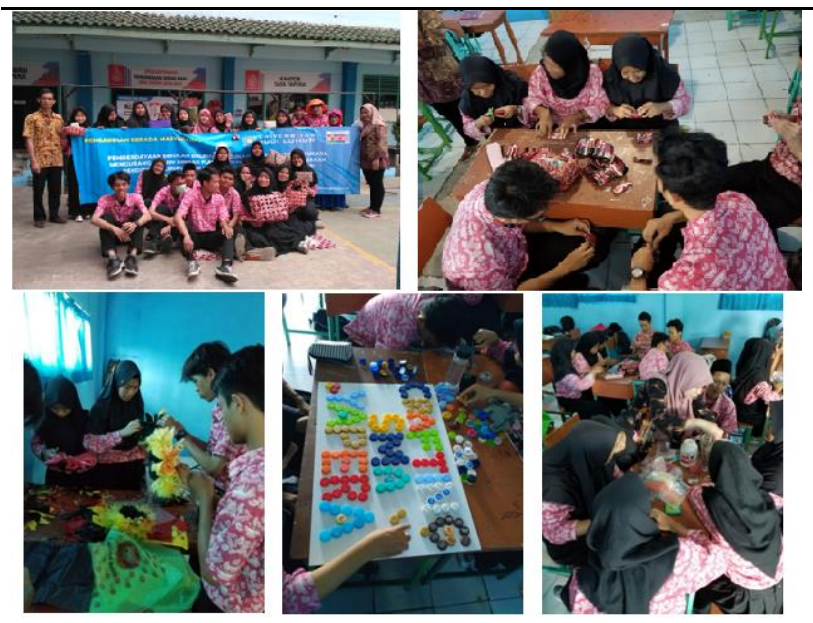

Gambar. 4 Pelaksanaan

\section{KESIMPULAN}

Kegiatan Pengabdian Kepada Masyarakat (PKM) ini disusun sebagai sumbangan nyata Universitas Budi Luhur untuk mengenalkan lebih luas program cinta lingkungan bersahabat dengan sampah tujuan-tujuan yang hendak dicapai yang relevan dengan Sustainable Development Goals (SDGs) khususnya tujuan nomor 12 yaitu konsumsi dan produksi yang bertanggung jawab. Hal ini dapat dicapai salah satunya dengan cara memanfaatkan kembali barang-barang yang secara umum dinilai sebagai sampah menjadi produk kreatif.

Selain itu, kegiatan ini juga bermanfaat dalam mengurangi dampak yang ditimbulkan oleh menumpuknya sampah, terutama sampah plastik. Kegiatan ini juga menunjukkan bahwa untuk mencapai tujuan tersebut, diperlukan kerjasama antar pihak, termasuk kolaborasi antar bidang studi dalam hal ini antara ilmu ekonomi dan bisnis dengan bidang teknologi informasi.

\section{UCAPAN TERIMAKASIH}

Ucapan terimakasih kami sampaikan kepada

1. Yayasan Pendidikan Budi Luhur Cakti Jakarta yang telah memberikan kontribusi dalam pelaksanaan kegiatan.

2. SMA An Nurmaniyah Ciledug Tangerang yang telah memberikan kesempatan kepada kami untuk melaksanakan kegiatan Pengabdian Kepada Masyarakat

3. Keluarga dan semua pihak yang telah memberikan suport sehingga kegiatan ini berjalan dengan baik dan lancar

\section{REFERENSI}

Oktober 2019

http://smasannurmaniyah.mysch.id// akses 7

http://Kompas.com akses 7 Oktober 2019

http://Kumparan.com akses 7 Oktober 2019

Setiyawati, Marina Ery. Fathihah Ranggauni Hardi. Putri Permatasari. (2019). Pemberdayaan Ibu Rumah Tangga Di Kelurahan Cinere Memanfaatkan Sampah Anorganik Menjadi Barang Kerajinan yang Bernilai Ekonomi. Jurnal Bakti Masyarakat Indonesia. Vol.2 No.1 Hal.123-128

Wicaksana, Bagus Ismail Adhi., dkk. (2028) Pemberian Value Added pada Sampah Rumah Tangga Organik Dimanfaatkan Sebagai Pupuk Kompos dan Pupuk Cair. Dimas Budi-Jurnal Pengabdian kepada Masyarakat Vol.2 No.2 ISSN 2598-0912 Hal.49-53 